Short Report

\title{
Serological Markers of Hepatitis A and B Virus Infection in Overseas Students
}

\author{
Shozo Nakamura \\ Tohoku University Health Center, Sendai 980
}

\begin{abstract}
Nakamura, S. Serological Markers of Hepatitis A and B Virus Infection in Overseas Students. Tohoku J. exp. Med., 1984, 142 (1) 115-116— Serological markers of hepatitis $\mathrm{A}$ and $\mathrm{B}$ virus infection were determined by radioimmunoassay in 83 overseas university students. Hepatitis B surface antigen (HBsAg) was detected in 8 students $(9.6 \%$ ), antibody to $\mathrm{HBsAg}$ and/or antibody to hepatitis B core antigen in $38(46 \%)$, and antibody to hepatitis A virus (anti-HAV) in 74 $(89 \%)$. These prevalences of hepatitis A and B markers were significantly higher than those in Japanese students. Liver function tests were abnormal in 7 overseas students $(8 \%)$. Among groups of the overseas students, East Asian groups showed high prevalences of hepatitis B markers. High prevalences of anti-HAV were demonstrated not only in Asian groups but also in South American group. - hepatitis B surface antigen; antibody to hepatitis B surface antigen; antibody to hepatitis B core antigen; antibody to hepatitis A virus; overseas university students
\end{abstract}

It is recently noted that Indochinese refugees arriving at the West have high prevalences of markers of hepatitis A and B virus infection (Chaudhary et al. 1981; Skinh $\phi$ j et al. 1981). We studied these markers in overseas students who mostly came from Asian countries with high prevalences of hepatitis A and B.

Subjects studied included 83 overseas students of Tohoku University. Seventy-four were males and 9 females. Hepatitis B surface antigen ( $\mathrm{HBsAg}$ ), antibody to HBsAg (anti$\mathrm{HBs}$ ), antibody to hepatitis $\mathrm{B}$ core antigen (anti- $\mathrm{HBc}$ ), hepatitis $\mathrm{B}$ e antigen ( $\mathrm{HBeAg}$ ), antibody to $\mathrm{HBeAg}$ (anti-HBe), antibody to hepatitis A virus (anti-HAV), and anti-HAV of the IgM-class were determined by radioimmunoassay (Ausria II-125, Ausab, Corab, Abbott-HBe, HAVAV, and HAVAV-M ; Abbott Laboratories). Subtypes of HBsAg were tested by the hemagglutination inhibition method and radioimmunoassay method (Ise et al. 1982) at Hepatitis Division of Tokyo Metropolitan Institute of Medical Science. The results were compared with those of Japanese students similarly studied (Nakamura 1982, 1983). As the overseas students, on the average, were older than the Japanese students, prevalences of hepatitis $\mathrm{A}$ and $\mathrm{B}$ antibodies were compared also between overseas students less than 26 years and the Japanese students. Comparisons of frequency were analyzed with Fischer's direct calculation method of probability.

HBsAg was detected in 8 overseas students $(9.6 \%)$. The prevalence was significantly higher than that in the Japanese students $(p<0.05)$ (Table 1). HBeAg was positive in 2 of the $8 \mathrm{HBsAg}$-positive overseas students $(25 \%)$, and anti-HBe in $6(75 \%)$. Of $23 \mathrm{HBsAg}$ positive Japanese students tested in 1982, $3(13 \%)$ showed HBeAg, and $19(83 \%)$ anti-HBe. As for HBsAg subtypes, 3 overseas students $(43 \%)$ had subtype $a d r$, and $4(57 \%) a d w$. Subtype $a d r$ was demonstrated in 21 Japanese students $(57 \%)$, and $a d w$ in $16(43 \%)$.

Received for publication, May 16, 1983. 
TABLE 1. Serological markers of hepatitis $A$ and $B$ virus infection in overseas students

\begin{tabular}{|c|c|c|c|c|c|c|}
\hline Group & Number & $\begin{array}{l}\text { Average } \\
\text { age } \\
\text { (years) }\end{array}$ & $\begin{array}{c}\mathrm{HBsAg} \\
\text { positive } \\
(\%)\end{array}$ & $\begin{array}{l}\text { Anti-HBs } \\
\text { and/or } \\
\text { anti-HBc } \\
\text { positive } \\
(\%)\end{array}$ & $\begin{array}{c}\text { Anti-HAV } \\
\text { positive } \\
(\%)\end{array}$ & $\begin{array}{c}\text { GOT } \\
\text { and/or } \\
\text { GPT } \\
\text { abnormal } \\
(\%)\end{array}$ \\
\hline Chinese & 22 & 31 & $2(9.1)$ & $11(50))^{* *}$ & $17(77)^{* * *}$ & $0(0)$ \\
\hline Taiwanese & 12 & 31 & $3(25.0)^{* *}$ & $5(42)$ 㐘 & $12(100)^{* * *}$ & $1(8)$ \\
\hline Korean & 24 & 32 & $3(12.5)$ & 17 (71)娄* & $23(96)^{* * *}$ & $1(4)$ \\
\hline Other Asian & 15 & 32 & $0(0)$ & $5(33)$ & $14(93)^{* * *}$ & $3(20)$ \\
\hline South American & 10 & 29 & $0(0)$ & $0(0)$ & $8(80)^{* * *}$ & $2(20)$ \\
\hline Total & 83 & 31 & $8(9.6)^{*}$ & $38(46)^{* * *}$ & $74(89)^{* * *}$ & $7(8)$ \\
\hline $\begin{array}{l}\text { Overseas } \\
\text { students } \\
\text { less than } \\
26 \text { years }\end{array}$ & 15 & 22 & $1(6.7)$ & $5(33)^{*}$ & $10(67)^{* * *}$ & $0(0)$ \\
\hline Japanese & 162 & 22 & $4(2.5)$ & $18 \dagger(11)$ & $2 / 65(3)$ & $6(4)$ \\
\hline
\end{tabular}

$\dagger$ Two students given hepatitis B immune globulin were excluded.

${ }^{*} p<0.05,{ }^{* *} p<0.01,{ }^{* * *} p<0.001$ for differences from Japanese students

\# $p<0.05$, \#\# $p<0.001$ for differences from South American group.

Anti-HBs and/or anti-HBc was positive in 38 (HBsAg-negative) overseas students $(46 \%)$. Two students had anti-HBs alone, and 3 anti- $\mathrm{HBc}$ alone. No $\mathrm{HBs} \mathrm{Ag}$-negative student showed high titer anti-HBc. Anti-HAV was positive in 74 overseas students $(89 \%)$. There were significant differences of anti-HBs and/or anti-HBc and of anti-HAV between the overseas students and the Japanese students and also between overseas students less than 26 years and the Japanese students (Table 1).

Glutamic oxalacetic transaminase and/or glutamic pyruvic transaminase were abnormal in 7 overseas students $(8 \%)$ (Table 1$)$.

Thus high prevalences of $\mathrm{HBsAg}$, anti-HBs and/or anti-HBc, and anti-HAV were observed in the overseas students as compared with the Japanese students. Among 5 groups of the overseas students, Chinese, Taiwanese, and Korean groups revealed high prevalences of hepatitis B markers, but South American group showed low prevalences. On the other hand, high prevalences of anti-HAV were found not only in 4 Asian groups but also in South American group (Table 1).

\section{References}

1) Chaudhary, R.K., Nicholls, E.S. \& Kennedy, D.A. (1981) Prevalence of hepatitis B markers in Indochinese refugees. Canad. med. Ass. J., 125, 1243-1246.

2) Ise, I., Gotanda, R., Baba, K., Tsuda, F., Naito, S., Tachibaba, K., Nakamura, T., Usuda, S., Imai, M. \& Nomura, M. (1982) Determination of subtypes of HBs antigen by solid phase RIA method. Acta hepatol. jap., 23, 685. (Japanese)

3) Nakamura, S. (1982) Serological markers of hepatitis A and B virus infection in university students. Tohoku J. exp. Med., 138, 237-238.

4) Nakamura, S. (1983) Decrease in female university students positive for hepatitis B e antigen. Tohoku J. exp. Med., 141, 123-124.

5) Skinh $\phi$ j. P., Aldershvile, J., Black, F., Kjersem, H., Kryger, P. \& Mathiesen, L. (1981) Viral hepatitis in Southeast Asian refugees. J. med. Virol., 7, 149-155. 